\title{
PELUANG TERJADINYA PENGANGGURAN DI PROVINSI BENGKULU : SEBERAPA BESAR?
}

\author{
Lisa Marini ${ }^{1)}$, Novi Tri Putri ${ }^{2)}$ \\ ${ }^{1}$ Jurusan Ekonomi Pembangunan Fakultas Ekonomi dan Bisnis Universitas Bengkulu \\ Email: lisamarini447@yahoo.co.id \\ ${ }^{2}$ Jurusan Ekonomi Pembangunan Fakultas Ekonomi dan Bisnis Universitas Bengkulu \\ Email: noviafr2606@gmail.com
}

\begin{abstract}
The aim of this research is to analyze how are opportunity occured unemployment based on characteristics of populations in Bengkulu province. Characteristics of populations that used are education, training/course certificate, age, gender, work experience, marital status, status in the family, and area of residence. The analytical method used to achieve this goal is the logistic regression analysis. Type of key data use row data derived from the National Labor Force Survey (Sakernas) February 2018. The result of the calculation using the program SPSS 20.0 was found that not all the variables of population characteristics significantly affect the chances of unemployment with a confidence level of 95 percent. Education and age are significantly affect of unemployment in Bengkulu Province, while training/course certificate, gender, work experience, marital status, status in the family and area residence are not significantly affect of unemployment in Bengkulu Province.
\end{abstract}

Keywords: Logistic Regression Analysis, National Labor Force Survey (Sakernas), Unemployment.

\section{PENDAHULUAN}

Pengangguran atau Tuna Karya adalah istilah untuk orang yang tidak bekerja sama sekali, sedang mencari kerja, bekerja kurang dari dua hari selama seminggu, atau seseorang yang sedang berusaha mendapatkan pekerjaan yang layak. Menurut Mantra (2009) pengangguran adalah bagian dari angkatan kerja yang sekarang ini tidak bekerja dan sedang aktif mencari pekerjaan. Konsep ini sering diartikan sebagai keadaan pengangguran terbuka. Secara umum ada empat jenis pengangguran jika ditinjau dari penyebabnya, yakni pengangguran friksional, pengangguran struktural, pengangguran musiman dan pengangguran siklikal.

Pengangguran merupakan salah satu permasalahan besar yang sering terjadi di sebuah negara. Istilah pengangguran merujuk kepada ketidakmampuan pemerintah dalam menyediakan lowongan pekerjaan untuk setiap penduduk yang ada dalam jangkauan pemerintahannya. Fenomena pengangguran terjadi sebagai dampak ketimpangan antara jumlah angkatan kerja dengan jumlah kesempatan kerja (lowongan pekerjaan). Fenomena pengangguran hanya terjadi ketika jumlah angkatan kerja yang ada pada suatu negara jauh lebih besar dibandingkan dengan jumlah kesempatan kerja atau lowongan kerja yang ada dalam negara tersebut. Dampaknya, sebagian angkatan kerja menjadi tidak dapat bekerja dan terpaksa menganggur untuk sementara waktu atau hingga tersedia lowongan pekerjaan tambahan yang baru dan yang sesuai dengan kualifikasi yang dimilikinya.

Pengangguran juga merupakan masalah di setiap negara, baik negara maju terlebih lagi di negara sedang berkembang seperti Indonesia. Menurut Budhi (2008) negara manapun di dunia ini baik yang dikategorikan negara maju maupun negara sedang berkembang senantiasa menghadapi masalah pengangguran, perbedaannya negara berkembang tidak dapat mampu memberikan tunjangan kepada warga negaranya yang menganggur, sedangkan negara maju mampu memberikan jaminan itu. 
Provinsi Bengkulu merupakan provinsi yang memiliki jumlah penduduk sebanyak 1,9 juta orang (keadaan Februari 2017). Dari jumlah tersebut sebanyak 1,39 juta orang atau sebesar 73,1 persen merupakan penduduk usia kerja. Dibandingkan dengan keadaan Agustus 2016 yang berjumlah 1,37 juta orang, jumlah penduduk usia kerja di Provinsi Bengkulu telah bertambah sebanyak 13,0 ribu orang atau naik sebesar 0,95 persen. Sedangkan jumlah pengangguran terbuka keadaan Februari 2017 di Provinsi Bengkulu sebanyak 29,0 ribu orang, bila angka pengangguran terbuka tersebut dibagi dengan jumlah angkatan kerja maka diperoleh Tingkat Pengangguran Terbuka (TPT) keadaan Februari 2017 sebesar 2,81 persen. Pengangguran terbuka (open unemployment) didasarkan pada konsep seluruh angkatan kerja yang mencari pekerjaan, baik yang mencari pekerjaan pertama kali maupun yang pernah bekerja sebelumnya.

Tabel 1 Jumlah Pengangguran Terbuka di Provinsi Bengkulu tahun 2013 - 2018

\begin{tabular}{ccc}
\hline Tahun & Jumlah Pengangguran (Jiwa) & TPT $(\%)$ \\
\hline 2013 & 40200 & 4,61 \\
2014 & 31300 & 3,5 \\
2015 & 46700 & 4,9 \\
2016 & 32900 & 3,30 \\
2017 & 36300 & 3,70 \\
2018 & 35059 & 3.8 \\
\hline
\end{tabular}

Sumber : Badan Pusat Statistik Provinsi Bengkulu, 2018.

Tingkat pengangguran di Provinsi Bengkulu digunakan untuk mengetahui jumlah pengangguran setiap tahunnya. Jumlah pengangguran di Provinsi Bengkulu paling tinggi terjadi pada tahun 2015 sebanyak 46.700 jiwa atau sekitar 4.9 persen. Sedangkan jumlah pengangguran terendah terjadi pada tahun 2014 sebanyak 31.300 jiwa atau sekitar 3,5 persen. Jika dilihat dari tabel 1.1 perkembangan tingkat pengangguran di Provinsi Bengkulu mengalami fluktuasi dari tahun 2013 hingga tahun 2018. Meskipun tingkat pengangguran di provinsi Bengkulu telah memperlihatkan tren penurunan namun hal ini tidak dapat menjamin bahwa keadaan masyarakat di Provinsi Bengkulu sudah baik. Selaras dengan penurunan tingkat pengangguran tersebut perkembangan tenaga kerja sektor informal di provinsi Bengkulu masih sangat tinggi. Jadi fenomena turunnya angka pengangguran di Provinsi Bengkulu tidak cukup kuat untuk membuktikan bahwa masalah pengangguran semakin baik dari tahun ke tahun.

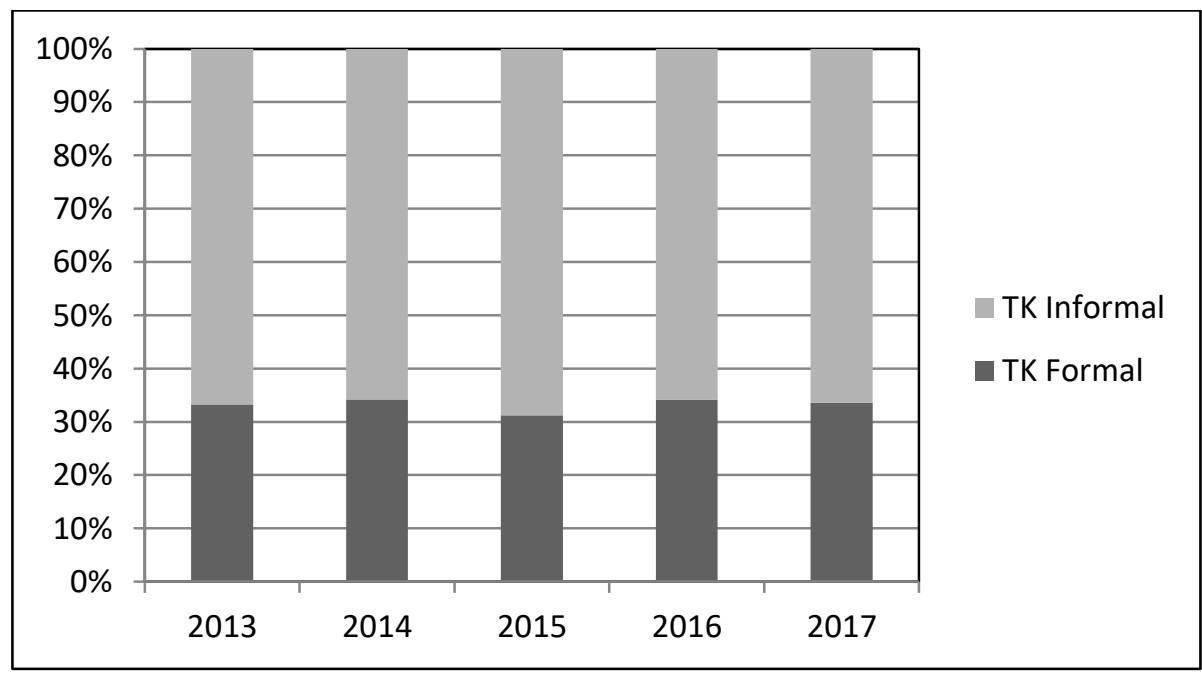

Sumber : Badan Pusat Statistik Provinsi Bengkulu, 2018.

Grafik 1 Perkembangan Tenaga Kerja Provinsi Bengkulu berdasarkan sektor Formal dan Informal. 
Komposisi tenaga kerja berdasarkan Status Pekerjaan Utama dikelompokkan menjadi tenaga kerja formal dan informal, menunjukkan bahwa porsi terbesar dalam 5 tahun terakhir adalah tenaga kerja informal. Grafik 1 menunjukkan bahwa tenaga kerja di Provinsi Bengkulu selama lima tahun didominasi oleh tenaga kerja informal mencapai kurang lebih 70 persen. Sementara itu tenaga kerja formal persentasenya hanya berkisar di angka 30 persen dari total jumlah tenaga kerja. Hal inilah yang menggambarkan bahwa turunnya tingkat pengangguran tidak menjamin bahwa kehidupan masyarakat Provinsi Bengkulu juga semakin membaik. Tingkat kemiskinan yang masih tinggi dan tingginya penyerapan tenaga kerja di sektor informal perlu di perhatikan agar penurunan tingkat pengangguran dapat berbanding lurus dengan tingkat kemakmuran masyarakat di Provinsi Bengkulu.

Dari uraian latar belakang dan data yang didapatkan maka dilakukan penelitian untuk melihat bagaimana peluang terjadinya pengangguran di Provinsi Bengkulu dilihat dari sisi karakteristik kependudukan yang dalam penelitian ini adalah pendidikan, sertifikat pelatihan/kursus, umur, jenis kelamin, pengalaman bekerja, status perkawinan, status dalam rumah tangga dan daerah tempat tinggal terhadap pengangguran di Provinsi Bengkulu. Adapun judul yang diangkat dalam penelitian ini yaitu "Analisis Faktor-Faktor Yang Mempengaruhi Peluang Terjadinya Pengangguran di Provinsi Bengkulu".

\section{LANDASAN TEORI}

\section{Ketenagakerjaan}

Konsep ketenagakerjaan yang digunakan Badan Pusat Statistik merujuk pada rekomendasi ILO. Hal ini dimaksudkan agar data ketenagakerjaan yang dihasilkan dapat dibandingkan secara internasional, tanpa mengabaikan kondisi ketenagakerjaan spesifik Indonesia. Pendekatan teori ketenagakerjaan yang digunakan dalam Sakernas adalah konsep Angkatan Kerja (Standard Labor ForceConcept).

Penduduk adalah semua orang yang berdomisili di wilayah geografis Republik Indonesia selama enam bulan atau lebih dan atau mreka yang berdomisili kurang dari enam bulan tetapi bertujuan untuk menetap. Berdasarkan konsep ketenagakerjaan, penduduk dikelompokkan menjadi penduduk umur kerja dan penduduk bukan umur kerja. Penduduk umur kerja dibedakan atas dua kelompok yaitu angkatan kerja dan bukan angkatan kerja. Pengukurannya didasarkan pada periode rujukan (time reference), yaitu kegiatan yang dilakukan selama seminggu yang lalu sampai sehari sebelum pencacahan.

Umur kerja adalah batas umur yang ditetapkan untuk pengelompokkan penduduk yang aktif secara ekonomi (economically active population). Indonesia menggunakan batas umur kerja 15 tahun (meskipun dalam survei dikumpulkan informasi dari umur 10 tahun) dan tanpa batas umur kerja bervariasi sesuai dengan kebutuhan/situasinya. Penduduk dalam umur kerja disebut tenaga kerja.

Angkatan kerja terdiri dari peduduk yang bekerja atau punya pekerjaan namun sementara tidak bekerja dan pengangguran. Sedangkan bukan angkatan kerja terdiri dari penduduk yang pada periode rujukan tidak mempunyai/melakukan aktivitas ekonomi, baik karena sekolah, mengurus rumah tangga atau lainnya(olahraga, kursus, piknik dan kegiatan sosial seperti berorganisasi, kerja bakti).

Bekerja adalah kegiatan melakukan pekarjaan dengan maksud memperoleh atau membantu memperoleh penghasilan atau keuntungan, paling sedikit selama satu jam dalam seminggu yang lalu. Penghasilan mencakup upah/gaji/pendapatan, termasuk semua tunjangan dan bonus bagi buruh/karyawan/pegawai dan hasil usaha berupa sewa, bunga atau keuntungan baik berupa uang atau barang bagi pengusaha. Bekerja selama satu jam itu harus dilakukan berturut-turut dan tidak terputus. Kegiatan bekerja ini mencakup yang sedang bekerja maupun yang punya pekerjaan tetapi dalam seminggu yang lalu sementara tidak bekerja, misalnya karena cuti, sakit dan sejenisnya. 
Pengangguran meliputi penduduk yang tidak bekerja atau sedang mencari pekerjaan, atau sedang mempersiapkan suatu usaha baru atau merasa tidak mungkin mendapat pekerjaan (putus asa), atau sudah diterima bekerja tetapi belum memulai bekerja. Yang dimaksud mencari pekerjaan adalah upaya yang dilakukan untuk memperoleh pekerjaan pada suatu periode rujukan.

Mempersiapkan usaha baru adalah suatu kegiatan yang dilakukan seseorang dalam rangka mempersiapkan usaha baru yang bertujuan memperoleh penghasilan dengan atau tanpa mempekerjakan buruh/karyawan dibayar maupun tak dibayar. Mempersiapkan usaha baru yang dimaksud disini tidak termasuk perluasan usaha dan sudah memiliki tindakan nyata seperti mengumpulkan modal atau perlengkapan, mencari lokasi atau tempat, mengurus surat ijin usaha dan sejenisnya. Merasa tidak mungkin mendapatkan pekerjaan (putus asa) adalah alasan bagi mereka yang berkali-kali mencari pekerjaan tetapi tidak berhasil mendapatkan pekerjaan yang diinginkan, atau mereka yang merasa karena keadaan/situasi/musim menyebabkan tidak mungkin mendapat pekerjaan yang diinginkan. Sudah diterima bekerja tetapi belum memulai bekerja adalah alasan bagi mereka yang tidak mencari pekerjaan maupun mempersiapkan usaha baru karena sudah diterima bekerja, tetapi pada saat pencacahan belum mulai bekerja.

Setengah penganggur adalah mereka yang bekerja dibawah jam kerja normal (kurang dari 35 jam seminggu). Setengah penganggur terdiri dari :

1. Setengah Penganggur Terpaksa, adalah mereka yang bekerja dibwah jam kerja normal (kurang dari 35 jam seminggu dan masih mecari pekerjaan atau masih bersedia menerima pekerjaan.

2. Setengah Penganggur Sukarela, adalah mereka yang bekerja dibawah jam kerja normal (kurang dari 35 jam seminggu), tetapu tidak mencari pekerjaan atau tidak bersedia menerima pekerjaan lain (sebagian pihak menyebutkan sebagai pekerja paruh waktu/part time worker).

Periode referensi merupakan periode waktu yang ditetapkan untuk membatasi keterangan responden (BPS, 2013). Periode referensi satu minggu yang paling banyak diterapkan negaranegara yang melaksanakan survei angkatan kerja, termasuk Indonesia salah satunya. Selain periode referensi seminggu yang lalu, dalam Sakernas juga dikenal kriteria satu jam secara berturut-turut. Kriteria ini digunakan dengan pertimbangan agar mencakup semua jenis pekerjaan yang mungkin ada pada suatu negara, termasuk didalamnya adalah pekerjaan dengan waktu singkat, pekerja bebas, stand-by work dan pekerjaan lainnya dengan waktu yang tak beraturan. Walaupun jumlahnya sangat kecil, tetapi ada orang Indonesia yang bekerja dengan kategori tersebut. Kriteria satu jam ini juga dikaitkan dengan definisi bekerja dan penganggur yang digunakan, dimana penganggur adalah situasi dari ketiadaan pekerjaan secara total (lack of work), apabila batas minimum dari jumlah jam kerja dinaikkan, maka akan mengubah definisi penganggur, yaitu bukan lagi ketiadaan pekerjaan secara total.

Berdasarkan argumen teknis, Organisasi Buruh Internasional (International Labour Organization - ILO) merekomendasikan untuk memperhatikan kriteria satu jam untuk menentukan seseorang dikatakan paling sedikit satu jam untuk menentukan seseorang dikatakan bekerja (employed). BPS menggunakan konsep bekerja paling sedikit satu jam secara berturut-turut dalam seminggu yang lalu untuk mengkategorikan seseorang sebagai bekerja (currently economically active population), tanpa memandang lapangan usaha, jabatan dan status pekerjaannya.

\section{Pasar Tenaga Kerja}

Dalam banyak pasar, harga-harga menyesuaikan agar jumlah penawaran seimbang dengan permintaan. Dalam pasar tenaga kerja yang ideal, upah harus disesuaikan untuk menyeimbangkan jumlah penawaran tenaga kerja dan jumlah permintaan tenaga kerja. Penyesuaian ini akan memastikan bahwa seluruh pekerja selalu memiliki pekerjaan bagi semua orang yang menginginkannya dengan kata lain jumlah penawaran tenaga kerja melebihi jumlah permintaan tenaga kerja (Mankiw, 2012). 
Pada gambar 2.2 menjelaskan dasar-dasar teori ekonomi dari upah minimum. Ketika peraturan upah minimum memaksa upah berada diatas titik keseimbangan penawaran dan permintaan tenaga kerja. Peraturan tersebut meningkatkan jumlah penawaran tenaga kerja dan mengurangi jumlah permintaan tenaga kerja dibandingkan dengan titik keseimbangan. Selanjutnya terjadi surplus tenaga kerja karena jumlah pekerja yang ingin bekerja lebih banyak daripada jumlah pekerjaan, sebagian pekerja pun tidak memiliki pekerjaan (menganggur).

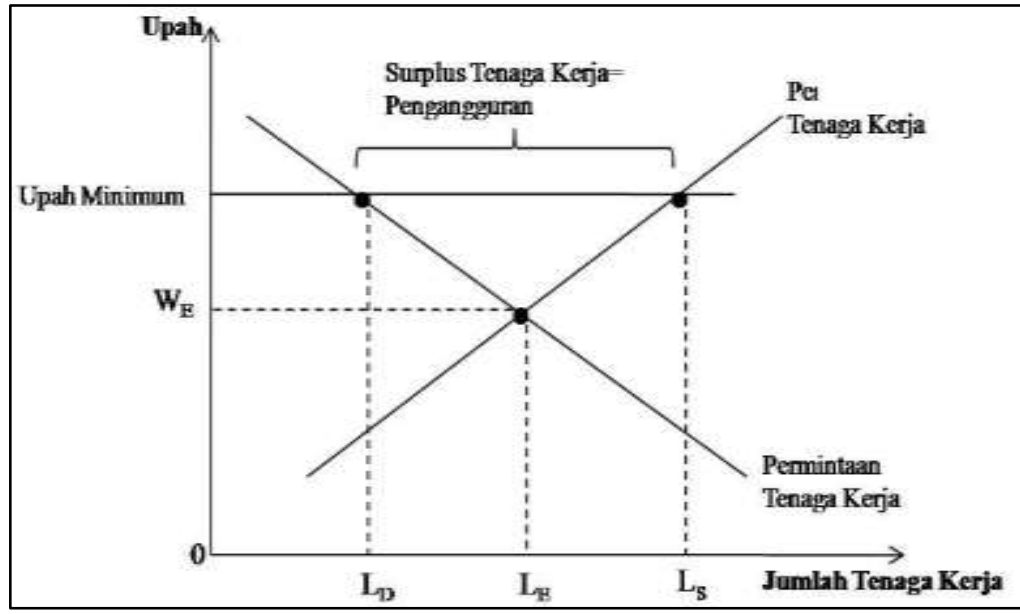

Sumber : Mankiw, 2012.

Gambar 1 Kurva Pengangguran Akibat Upah di Atas Keseimbangan

Berdasarkan kurva di atas dijelaskan bahwa di pasar tenaga kerja, $\mathrm{W}_{\mathrm{E}}$ adalah upah pada titik keseimbangan penawaran dan permintaan. Pada upah keseimbangan ini, jumlah penawaran dan permintaan tenaga kerja adalah $\mathrm{L}_{\mathrm{E}}$. Sebaliknya, jika upah tersebut dipaksa agar tetap berada di atas titik keseimbangannya, mungkin karena adanyaperaturan upah minimum, maka jumlah penawaran tenaga kerja meningkat menjadi $\mathrm{L}_{S}$, dan jumlah permintaan tenaga kerja menurun menjadi $\mathrm{L}_{\mathrm{D}}$. Surplus tenaga kerja yang dihasilkan, $\mathrm{L}_{\mathrm{S}}-\mathrm{L}_{\mathrm{D}}$, adalah pengangguran. Meskipun ditampilkan untuk memperlihatkan pengaruhdari upah minimum,pada kurva diatas juga menggambarkan poin yang mana bersifat lebih umum jika upah dipertahankan di atas titik keseimbangan karena segala alasan, maka hasilnya adalah pengangguran (Mankiw, 2012).

Pasar kerja diasumsikan terjadi keseimbangan penawaran dan permintaan tenaga kerja pada tinggkat upah tertentu dan jumlah pekerja tertentu pula. Namun dalam pelaksanaanya ada campur tangan pemerintah dalam menentukan tingkat upah minimum. Jumlah perusahaan bisa berkurang karena pemberlakuan tingkat upah minimum tidak bisa ditanggung oleh semua perusahaan. Hanya perusahaan yang sanggup menanggung upah minimum yang dapat bertahan.

Teori kesempatan kerja oleh Von Mises dalam Aryati (2014) menyebutkan bahwa dipasar yang tak terkendala, pengangguran yang terjadi adalah pengangguran sukarela. Manusia bekerja karena memilih untuk mengantisipasi hasil pekerjaannya daripada menyia-nyiakan tenaga jika ia tidak bekerja. Mereka akan berhenti saat merasa bahwa menikmati waktu senggang bukan merupakan kegiatan yang menyia-nyiakan kesempatan kerja, atau saat merasa manfaat dari waktu senggangnya dianggap lebih berharga dari pada penambah kepuasan yang mungkin akan didapatnya bila tetap bekerja. Kesempatan kerja akan meningkat dan upah juga akan bergerak naik selama tingkat upah yang berlaku dinilai lebih rendah oleh para pengusahan daripada nilai marjinal produk. Tetapi para pekerja akan bersikeras agar tidak dipekerjakan dibawah tingkat upah minimum sebelum bersedia dipekerjakan. Akibat yang ditimbulkan dari tingkat upah minimu bergerak lebih tinggi daripada yang dikehendaki dipasar bebas, yaitu berupa surplus tenaga kerja yang tak terjual karena harganya sudah sangat tinggi. Semakin cepat para pekerja mengijinkan upah mereka turun, maka semakin cepat pengangguran hilang. 


\section{Pengangguran}

Pengertian pengangguran dalam arti luas adalah penduduk yang tidak berkerja atau tidak memiliki pekerjaan. Menurut Badan Pusat Statistik (BPS) dalam indikator ketenagakerjaan, pengangguran adalah penduduk umur 15 tahun ke atas yang tidak bekerja namun sedang mencari pekerjaan atau sedang mempersiapkan suatu usaha baru atau penduduk yang tidak mencari pekerjaan karena sudah diterima bekerja tetapi belum mulai bekerja.

Menurut Sukirno (2006) pengangguran adalah seseorang yang sudah digolongkan dalam angkatan kerja yang secara aktif sedang mencari pekerjaan pada suatu tingkat upah tertentu, tetapi tidak dapat memperoleh pekerjaan yang diinginkannya. Berdasarkan pengertian tersebut, untuk dikatakan sebagai pengangguran seseorang tidak cukup tidak memiliki pekerjaan dan tidak bekerja tetapi harus aktif mencari pekerjaan.

Sukirno (2006) menyebutkan bahwa ada dua hal yang membedakan jenis-jenis penganggguran yakni berdasakan penyebab dan ciri-cirinya.

a. Jenis Pengangguran Berdasarkan Penyebabnya

1. Pengangguran Friksional

2. Pengangguran Siklikal

3. Pengangguran Struktural

4. Pengangguran Teknologi

b. Jenis Pengangguran Berdasarkan Ciri-cirinya

1. Pengangguran Terbuka

2. Pengangguran Tersembunyi

3. Pengangguran Musiman

4. Setengah Menganggur

Faktor- faktor yang menyebabkan terjadinya pengangguran (Sukirno, 2006) antara lain :

1. Besarnya angkatan kerja tidak seimbang dengan kesempatan kerja. Hal ini terjadi saat jumlah angkatan kerja lebih besar daripada kesempatan kerja yang tersedia.

2. Struktur lapangan kerja tidak seimbang.

3. Kebutuhan jumlah dan jenis tenaga kerja terdidik dan penyediaan tenaga kerja terdidik tidak seimbang.

4. Meningkatnya peranan dan aspirasi angkatan kerja wanita dalam seluruh struktur angkatan kerja Indonesia.

5. Penyediaan dan pemanfaatan tenaga kerja antar daerah tidak seimbang.

Setidaknya terdapat delapan paradoks masalah pengangguran di Indonesia (Shafiq, 2004). Pertama, penduduk semakin banyak bermigrasi ke perkotaan padahal perkotaan mempunyai tingkat pengangguran yang lebih tinggi daripada daerah yang lain. Kedua, angka pengangguran untuk generasi muda (mereka yang baru lulus sekolah) lebih tinggi daripada usia 30 tahun ke atas. Ketiga, angka pengangguran untuk wanita lebih tinggi daripada pria. Keempat, tingkat pengangguran untuk angkatan kerja dengan kapasitas pendidikan yang lebih tinggi menunjukkan angka yang lebih tinggi dibandingkan tingkat pendidikan SD atau SLTP. Kelima, angka pengangguran untuk mereka yang bersekolah di sekolah umum lebih besar daripada mereka yang bersekolah di sekolah kejuruan. Keenam, semenjak tahun 1970 Indonesia menunjukkan performa ekonomi yang bagus, namun hal itu ternyata tidak disertai dengan penyerapan angkatan kerja. Ketujuh, tidak ada perbedaan angka pengangguran antarmasyarakat dengan tingkat pendapatan yang berbeda. Terakhir, angka pengangguran untuk daerah Sumatera Selatan, Aceh, Kalimantan Timur, NTT, Maluku, dan Irian Jaya lebih besar daripada provinsi tetangganya NTB, Kalimantan Tengah, dan Lampung tanpa ada penjelasan yang masuk akal. Penyebab tingginya angka pengangguran di daerah perkotaan tersebut disebabkan oleh banyaknya migrasi masuk ke 
perkotaan akibat timbul kesadaran bahwa di perkotaan pekerjaan lebih mudah didapatkan (Shafiq, 2004). Pendapat tersebut sesuai dengan data yang diperoleh dari Badan Pusat Statistik terkait tingkat pengangguran di desa dan kota selama tahun 2010 sampai 2014.

\section{METODE PENELITIAN}

Penelitian yang berjudul "Analisis Probabilitas Pengangguran di Provinsi Bengkulu " ini menggunakan metode deskriptif analisis dengan pendekatan kuantitatif, yaitu hasil penelitian yang kemudian diolah dan dianalisis untuk diambil kesimpulannya, artinya penelitian yang dilakukan adalah penelitian yang menekankan analisisnya pada data-data numeric (angka) dengan menggunakan metode penelitian ini akan diketahui pegaruh yang signifikan antara variabel yang diteliti, sehingga menghasilkan kesimpulan yang akan memperjelas gambaran mengenai objek yang diteliti.

Data yang digunakan dalam penelitian ini adalah jenis data sekunder. Teknik pengumpulan data dalam penelitian ini menggunakan metode dokumentasi, hal ini dilakukan dengan cara melakukan penelusuran dan pencatatan informasi yang diperlukan yaitu berupa data mentah (row data) hasil Survei Angkatan Kerja Nasional (SAKERNAS) Februari 2018 di Provinsi Bengkulu. Data yang dikumpulkan adalah keterangan mengenai keadaan umum setiap anggota rumah tangga yang mencakup nama, hubungan dengan kepala rumah tangga, jenis kelamin dan umur. Untuk anggota rumah tangga yang berumur 10 tahun ke atas akan ditanyakan keterangan mengenai status perkawinan, pendidikan dan pekerjaan.

Data mentah hasil SAKERNAS Februari 2018 ini berjumlah 840 rumah tangga atau 2.053 orang, sedangkan data yang digunakan dalam penelitian ini yaitu sebanyak 1.462 orang terdiri dari seluruh anggota keluarga berusia 15 tahun keatas yang bekerja dan menganggur. Data yang telah tersedia diolah dengan menggunakan program SPSS 20. Metode analisis data yang digunakan dalam penelitian ini adalah Logistic Regression Model (LRM) untuk mengestimasi pengangguran di Provinsi Bengkulu tahun 2018 berdasarkan faktor-faktor yang mempengaruhinya yaitu pendidikan, sertifikat pelatihan/kursus, umur, jenis kelamin, pengalaman bekerja, status perkawinan, status dalam rumah tangga dan daerah tempat tinggal.

\section{Analisis Model Binary Logistic Regression}

Penggunaan model regresi logistik ini dianggap sebagai alat yang paling tepat untuk menganalisis data dalam penelitian ini, karena variabel dependennya bersifat dikotomi atau multinominal yaitu lebih dari satu atribut. Regresi logistik dengan dua pilihan sering disebut Binary Logistic Regression (BLR). Karena model yang dihasilkan dengan regresi logistik bersifat non linear, persamaan yang digunakan untuk mendiskripsikan hasil sedikit lebih kompleks dibanding dengan regresi berganda. Variabel hasil adalah probabilitas mendapatkan dua hasil atau lebih berdasarkan fungsi non linear dari kombinasi linear dari sejumlah variabel (predictors) dan model Binary Logistic Regression memenuhi model distribusi kumulatif (CDF) yang mampu menjamin bahwa nilainya terletak antara 0 dan 1 sehingga dapat membuat model regresi dimana respon dari variabel dependen bersifat dikotomis yakni 0 dan 1 terpenuhi . Persamaan model Binary Logistic Regression dan bagaimana mengestimasikannya dalam penelitian ini dapat dinyatakan sebagai berikut :

Probabilitas seseorang untuk menganggur, sbb:

$$
P_{i}=\frac{1}{1+e_{-}-r_{i}}
$$

Kalau kita kalikan dengan sisi kanan persamaan (3.2) tersebut dengan $e^{z i}$ maka akan menghasilkan persamaan sbb: 


$$
P_{I}=\frac{1}{1+e^{-z i}}=\frac{e^{z i}}{1+e^{z t}}
$$

Sedangkan probabilitas seseorang tidak menganggur (bekerja) $\left(1-P_{i}\right)$ sbb:

$$
1-P_{i}=1 \quad \frac{e^{z i}}{1+e^{z i}}=\frac{e^{z i}}{1+e^{z i}}
$$

Sehingga dari persamaan (3.3) dan (3.4) kita bisa menghitung rasio probabilitas seseorang untuk menganggur dan tidak menganggur (bekerja) sbb :

$$
\frac{P_{\mathrm{i}}}{1-P_{i}}=\left(\underset{1+\mathrm{e}^{\mathrm{xi}}}{e^{z i}}\right)\left(\frac{1+e^{z \mathrm{i}}}{1}\right)=e^{s i}
$$

Rasio di dalam persamaan (3.5) tersebut dengan odd ratio yaitu rasio probabilitas seseorang untuk menganggur dengan tidak menganggur (bekerja). Kemudian kita transpormasi persamaan tersebut menjadi model logaritma natural (Ln) sbb:

$$
\ln \left(\frac{P_{i}}{1-P_{i}}\right)=Z_{i} \ln e=Z_{i}
$$

Persamaan (3.6) tersebut merupakan persamaan regresi logistik, karena hanya ada satu variabel independen sehingga merupakan regresi logistik dengan satu variabel independen. Bagaimana kalau kita mempunyai lebih dari satu variabel independen misalnya dalam peluang seseorang menjadi pengangguran dapat dipengaruhi oleh beberapa variabel seperti, variabel pendidikan, variabel sertifikat pelatihan/kursus, variabel umur, variabel jenis kelamin, variabel pengalaman bekerja, variabel status perkawinan, variabel status dalam rumah tangga dan variabel daerah tempat tinggal. Variabel independen tersebut bisa kita tulis dengan menggunakan persamaan sbb:

$$
\begin{aligned}
\mathrm{Zi}= & \beta_{0}+\beta_{1} \mathrm{X} 1+\beta_{2} \mathrm{D} 2+\beta_{3} \mathrm{X} 3+\beta_{4} \mathrm{D} 4+\beta_{5} \mathrm{X} 5+\beta_{6} \mathrm{X} 6+\beta_{7} \mathrm{D} 7 \\
& +\beta_{8} \mathrm{D} 8+\varepsilon \mathrm{i}
\end{aligned}
$$

Keterangan

$\mathrm{Zi}=$ probabilitias sesorang untuk menganggur atau tidak menganggur

$\mathrm{X}_{1}=$ pendidikan

$\mathrm{D}_{2}=$ Dummy sertifikat pelatihan/ kursus

$\mathrm{X}_{3}=$ umur

$\mathrm{D}_{4}=$ Dummy jenis kelamin

$\mathrm{X}_{5}=$ pengalaman bekerja

$\mathrm{X}_{6}=$ status perkawinan

$\mathrm{D}_{7}=$ Dummy status dalam rumah tangga

$\mathrm{D}_{8}=$ Dummy daerah tempat tinggal

$\beta_{0}=$ intersep / konstanta regresi

$\beta_{1}, \beta_{2}, \beta_{3}, \beta_{4}, \beta_{5}, \beta_{6}, \beta_{7}, \beta_{8}=$ koefisien regresi

$\mu_{\mathrm{i}}=$ error terms

\section{HASIL DAN PEMBAHASAN}

Kondisi ketenagakerjaan di Provinsi Bengkulu dapat dilihat dari pada tabel 4.1. Penduduk Provinsi Bengkulu yang berumur 15 tahun keatas dari tahun 2013 - 2017 terus mengalami peningkatan, pada tahun 2013 jumlah penduduk Provinsi Bengkulu yang berumur 15 tahun keatas sebanyak 1.290.430 orang dan pada tahun 2017 meningkat menjadi sebanyak 1.398 .542 orang. Perkembangan jumlah angkatan kerja di Provinsi Bengkulu juga mengalami peningkatan dari tahun 2013 - 2016, pada tahun 2013 jumlah angkatan kerja sebanyak 827.233 orang dan pada tahun 2016 sebanyak 997.913 orang dan mengalami sedikit penurunan di tahun 2017 menjadi 969.225 orang. Perkembangan jumlah bukan angkatan kerja di Provinsi Bengkulu mengalami trend yang menurun dari tahun 2013 - 2017, pada tahun 2013 jumlah bukan angkatan kerja sebanyak 418.197 orang dan pada tahun 2016 sebanyak 374.864 orang dan kembali mengalami kenaikan pada tahun 2017 menjadi 429.287 orang. Sedangkan jumlah penduduk yang sekolah 
tertinggi terjadi pada tahun 2014 yaitu sebanyak 147.706 orang dan jumlah penduduk yang mengurus rumah tertinggi terjadi pada tahun 2017 yaitu sebanyak 243.931 orang.

Tabel 2. Perkembangan Penduduk berdasarkan Angkatan Kerja dan Bukan Angkatan Kerja di Provinsi Bengkulu Tahun 2013-2017 (orang)

\begin{tabular}{lrrrrr}
\hline Jenis Kegiatan & 2013 & 2014 & 2015 & 2016 & 2017 \\
\hline $\begin{array}{l}\text { Penduduk } \\
\text { Berumur } \\
\text { Tahun ke Atas }\end{array}$ & 1.290 .430 & 1.318 .003 & 1.345 .754 & 1.372 .777 & 1.398 .542 \\
Angkatan Kerja & 872.233 & 900.054 & 951.007 & 997.913 & 969.225 \\
Bekerja & 823.048 & 868.794 & 904.317 & 964.971 & 932.976 \\
$\begin{array}{l}\text { Pengangguran } \\
\text { Terbuka }\end{array}$ & 40.185 & 31.260 & 46.690 & 32.942 & 36.279 \\
$\begin{array}{l}\text { Bukan Angkatan } \\
\text { Kerja }\end{array}$ & 418.197 & 417.949 & 394.747 & 374.864 & 429.287 \\
$\begin{array}{l}\text { Sekolah } \\
\text { Mengurus Rumah }\end{array}$ & 106.412 & 147.706 & 123.137 & 122.114 & 138.443 \\
Tangga & 237.247 & 219.231 & 194.008 & 210.081 & 243.931 \\
$\begin{array}{l}\text { Lainnya } \\
\text { TPAK }\end{array}$ & 74.538 & 51.012 & 41.629 & 42.669 & 46.913 \\
TPT & 67,59 & 68,29 & 70,67 & 72,69 & 69,3 \\
\hline Sumber:Badan Pusat Statistik Provinsi Bengkulu, 2018 & & 3,3 & 3,74 \\
\hline
\end{tabular}

Sumber : Badan Pusat Statistik Provinsi Bengkulu, 2018.

Jika dilihat dari Tabel 2 Tingkat Partisipasi Angkatan Kerja (TPAK) tertinggi terjadi di tahun 2016 yaitu sebesar 72,69 persen dan TPAK terendah terjadi pada tahun 2013 yaitu sebesar 67,59 persen. Jumlah pengangguran di Provinsi Bengkulu mengalami fluktuasi dari tahun 2013-2017. Pengangguran paling tinggi terjadi pada tahun 2015 sebanyak 46.690 jiwa atau sekitar 4.91 persen. Sedangkan jumlah pengangguran terendah terjadi pada tahun 2014 sebanyak 31.260 jiwa atau sekitar 3,47 persen.

Penelitian ini untuk mengetahui besarnya pengaruh pendidikan, sertifikat pelatihan/kursus, umur, jenis kelamin, pengalaman bekerja, status perkawinan, status dalam rumah tangga dan daerah tempat tinggal terhadap pengangguran di Provinsi Bengkulu. Alat analisis yang dipakai adalah model logit atau Binary Logistic Regression. Ada sebanyak 1462 responden yang dipilih dalam penelitian ini. Hasil perhitungan antara variabel terikat dengan variabel bebas menggunakan metode logit, maka didapatkan persamaan logit sebagai berikut:

$$
\begin{aligned}
\mathrm{Zi}= & 0,030+1,550 \mathrm{X} 1+1,249 \mathrm{D} 2+0,300 \mathrm{X} 3+0,993 \mathrm{D} 4+0,796 \mathrm{X} 5+0,639 \mathrm{X} 6+3,151 \mathrm{D} 7 \\
& +0,984 \mathrm{D} 8+\varepsilon \mathrm{i}
\end{aligned}
$$

Keterangan :

$L i$ = variabel dependen dummy, bernilai 1 apabila pengangguran dan bernilai 0 apabila bekerja .

$B=$ koefisien variabel independen.

$\mathrm{X} 1=$ pendidikan

$\mathrm{X} 2$ = sertifikat pelatihan/kursus

$\mathrm{X} 3$ = umur

$\mathrm{X} 4$ = jenis kelamin

$\mathrm{X} 5$ = pengalaman bekerja

$\mathrm{X} 6$ = status perkawinan 
$\mathrm{X} 7$ = status dalam rumah tangga

$\mathrm{X} 8$ = daerah tempat tinggal

$\varepsilon i=$ error terms

Dari hasil estimasi regresi logistik menunjukkan bahwa tidak seluruh variabel karakteristik kependudukan memiliki peluang untuk mempengaruhi terjadinya pengangguran di Provinsi Bengkulu. Variabel pendidikan dan umur memiliki pengaruh signifikan terhadap peluang terjadinya pengangguran di Provinsi Bengkulu, sedangkan variabel sertifikat pelatihan/kursus, jenis kelamin, pengalaman bekerja, status perkawinan, status dalam rumah tangga dan daerah tempat tinggal tidak signifikan berpengaruh terhadap peluang terjadinya pengangguran di Provinsi Bengkulu. Hasil analisis regresi logistik menunjukkan bahwa variabel pendidikan berpengaruh secara signifikan berpeluang dan memiliki koefisien positif $(+)$ terhadap pengangguran di Provinsi Bengkulu. Dengan nilai odd ratio sebesar 1,5 bermakna setiap kenaikan satu jenjang pendidikan, maka akan menaikkan peluang seseorang untuk menganggur sebesar 1,5 kali. Hal ini sejalan dengan temuan Tobing (2011) yang menyatakan bahwa orang yang berpendidikan tinggi cenderung untuk memilih-milih lowongan pekerjaan yang ada untuk dirinya sehingga terhitung sebagai pengangguran. Sejalan dengan hasil analisis deskriptif bahwa dari 32 orang responden yang berstatus pengangguran sebanyak 19 responden tersebut telah menamatkan jenjang pendidikan sekolah tinggi, hal ini pun terbukti terjadi di Provinsi Bengkulu karena berdasarkan hasil Sakernas Februari dan Agustus 2017, TPT tertinggi menurut tingkat pendidikan terdapat pada pendidikan sekolah tinggi yaitu sebesar 5,42 persen, sementara pendidikan menengah menempati urutan kedua yaitu sebesar 4,25 persen dan pendidikan rendah menempati posisi terakhir sebesar 1,77 persen.

Hal ini membuktikan bahwa setiap kenaikan satu jenjang pendidikan berpotensi berpeluang lebih besar menyebabkan seseorang untuk menjadi pengangguran di Provinsi Bengkulu, selain itu apabila pengangguran yang lebih tinggi di kalangan orang-orang dengan pendidikan tinggi juga menunjukkan kurangnya pekerjaan teknis yang profesional dan tingkat tinggi yang memadai untuk para lulusan sekolah tinggi di Provinsi Bengkulu. Pendidikan diposisikan masyarakat sebagai sarana untuk peningkatan kesejahteraan melalui pemanfatan kesempatan kerja yang ada. Dalam arti lain, tujuan akhir program pendidikan bagi masyarakat pengguna jasa pendidikan adalah teraihnya lapangan kerja yang diharapkan. Atau setidak-tidaknya, setelah lulus dapat bekerja di sektor formal yang memiliki nilai "gengsi" yang lebih tinggi di banding sektor informal.

Sejalan dengan penelitian Yuliatin (2009) variabel umur berpengaruh secara signifikan berpeluang dan memiliki koefisien negatif (-) terhadap pengangguran, dalam penelitian ini menunjukkan bahwa nilai odd ratio variabel umur sebesar 0,3 , yang menunjukkan bahwa jika umur bertambah 1 tahun, maka peluang mereka menganggur 0,3 kali dibandingkan tidak menganggur. Dengan kata lain semakin muda umur seseorang, maka mereka lebih berpeluang untuk mengangur. Hal ini juga sejalan dengan hasil penelitian Fa'atin (2010) yang menyatakan bahwa semakin tinggi umur, kecenderungan menjadi penganggur makin rendah. Sejalan dengan hasil analisis deskriptif bahwa dari 32 orang responden yang berstatus pengangguran sebanyak 17 responden tersebut berusia 1524 tahun, sebanyak 8 responden berusia 25-34 tahun, sebanyak 4 responden berusia 35-44 tahun, sebanyak 2 responden berusia 45-54 tahun, sebanyak 1 responden berusia 55-64 tahun dan tidak ada responden yang berstatus menganggur diusia 65 tahun keatas. Dari hasil analisis deskriptif tersebut menggambarkan bahwa semakin tinggi usia responden maka semakin kecil peluang responden tersebut berstatus menganggur. Hal ini pun terbukti terjadi di Provinsi Bengkulu, karena berdasarkan hasil Sakernas Februari dan Agustus 2017, jumlah penganggur usia muda (15-24 tahun) terhadap total penganggur cukup tinggi yaitu sebesar 56,20 persen. Angka ini dapat diartikan dari 100 orang penganggur terdapat sejumlah 56 orang penganggur yang berumur antara 15 sampai 24 tahun.

Fenomena ini menunjukkan belum cukupnya persediaan lapangan pekerjaan yang cocok bagi mereka. Kelompok usia muda ini yang juga merupakan angkatan kerja baru yang belum siap 
memasuki dunia kerja. Ada beberapa latar belakang mengapa kelompok usia muda itu ikut terjun ke pasar kerja, antara lain kesulitan ekonomi keluarga sehingga memaksa mereka untuk berhenti sekolah/kuliah dan terpaksa memasuki dunia kerja. Sebaliknya, sulitnya mendapatkan pekerjaan karena terbatasnya lapangan pekerjaan serta kurangnya pengalaman dan keahlian menyebabkan mereka ikut terjebak dalam kelompok pengangguran, sehingga menambah akumulasi jumlah pengangguran menjadi lebih banyak lagi. Faktor-faktor lainnya ialah kelompok usia muda umumnya masih bersifat idealis termasuk dalam memilih pekerjaan, misalnya sesuai keinginan, keahlian, hobi, standar gaji, dan gengsi. Akibatnya lapangan pekerjaan mereka menjadi terbatas. Selain itu, kelompok usia ini belum memiliki banyak beban tanggungan ekonomi keluarga dan masih ada jaring pengaman ekonomi baginya yaitu keluarga dan masyarakat sosialnya. Hal ini lah yang memperbesar peluang seseorang untuk menganggur.

Pengujian statistik dalam penelitian ini menghasilkan variabel jenis kelamin tidak signifikan mempengaruhi peluang terjadinya pengangguran di Provinsi Bengkulu. Menurut data BPS tentang Rasio Penduduk Bekerja menurut jenis kelamin memperlihatkan bahwa jumlah rasio bekerja penduduk laki-laki yaitu sebesar 81,44 persen dan untuk perempuan sebesar 51,43 persen, jika dikalkulasi kan bahwa perbedaan rasio bekerja pada penduduk laki-laki hanya sebesar 1,5 kali lebih besar dibandingkan rasio penduduk bekerja pada penduduk perempuan. Hal ini juga sejalan dengan hasil analisis deskriptif bahwa dari 32 orang responden yang berstatus pengangguran sebanyak 17 responden berjenis kelamin laki-laki dan sebanyak 15 responden berjenis kelamin perempuan, ini menunjukkan bahwa tidak ada perbedaan yang signifikan antara peluang laki-laki dan perempuan untuk menganggur. Hal ini juga mengambarkan bahwa telah terjadi kesetaraan kesempatan bekerja bagi laki-laki dan perempuan di Provinsi Bengkulu. Namun kenyataan ini berlawanan dengan teori Barret dan Morgenstern (1974) yang mengatakan angka pengangguran wanita lebih tinggi dikarenakan perempuan membutuhkan waktu yang lebih lama dalam menemukan pekerjaan yang cocok dibandingkan laki-laki.

Pengujian statistik dalam penelitian ini juga menghasilkan variabel pengalaman bekerja tidak signifikan mempengaruhi peluang terjadinya pengangguran di Provinsi Bengkulu. Hal ini sejalan dengan hasil analisis deskriptif yang menunjukkan bahwa dari 1430 responden yang berstatus bekerja sebesar 58 persen tidak memiliki pengalaman bekerja dan sisanya 42 persen memiliki pengalaman bekerja, ini memperlihatkan bahwa seseorang yang memiliki atau tidak memiliki pengalaman bekerja mempunyai peluang yang sama untuk diterima bekerja di Provinsi Bengkulu bahkan persentase penduduk yang tidak memiliki pengalaman bekerja lebih banyak yang bekerja di Provinsi Bengkulu. Kenyataan ini tidak sejalan dengan penelitian yang dilakukan oleh Setiawan (2010) menunjukkan bahwa variabel pengalaman kerja memiliki pengaruh positif dan signifikan terhadap lama mencari kerja bagi pengangguran.

Begitupun dengan pengujian statistik terhadap variabel sertifikat pelatihan/ kursus juga tidak signifikan mempengaruhi peluang terjadinya pengangguran di Provinsi Bengkulu. Hal ini sejalan dengan hasil analisis deskriptif yang menunjukkan bahwa dari 1430 responden yang berstatus bekerja sebesar 84 persen tidak memiliki sertifikat pelatihan/kursus dan sisanya sebesar 16 persen memiliki sertifikat pelatihan/kursus, ini menunjukkan bahwa penduduk yang tidak memiliki sertifikat pelatihan/kursus mempunyai peluang yang lebih besar untuk bekerja di Provinsi Bengkulu, diperkirakan bahwa sertifikat pelatihan/kursus bukan merupakan kualifikasi utama dalam pencarian lowongan pekerjaan di Provinsi Bengkulu sehingga ada tidaknya sertifikat pelatihan/kursus tidak akan berpeluang mempengaruhi seseorang untuk menganggur. Kenyataan ini juga tidak sejalan dengan penelitian yang dilakukan oleh Hayati (2016) bahwa skill yang dalam penelitian ini adalah memiliki sertifikat pelatihan/kursus signifikan mempengaruhi pengangguran.

Selanjutnya pengujian statistik yang dilakukan terhadap variabel status perkawinan juga tidak signifikan mempengaruhi peluang terjadinya pengangguran di Provinsi Bengkulu. Hal ini sejalan dengan hasil analisis deskriptif bahwa dari 32 orang responden yang berstatus pengangguran 
sebanyak sebanyak 19 orang responden yang berstatus belum kawin, sebanyak 10 responden yang bersatus kawin dan sebanyak 3 responden yang berstatus cerai. Hal ini menunjukkan bahwa jika seseorang mengubah status perkawinannya maka tidak akan menyebabkan peluang seseorang untuk menganggur itu semakin besar, sebaliknya peluang untuk bekerja ketika seseorang mengubah statusnya dari belum menikah menjadi menikah akan semakin besar karena dapat dilihat dari hasil analisis deskriptif yang menunjukkan dari 1430 responden yang bekerja sebesar 13 persen berstatus belum kawin, sebesar 80 persen berstatus kawin dan sisanya sebesar 7 persen berstatus cerai baik cerai hidup maupun cerai mati. Kenyataan ini berlawanan dengan penelitian Astuti (2013) yang menyatakan bahwa status perkawinan bagi seseorang yang sudah menikah membuat seseorang lebih sulit dalam mendapatkan pekerjaan sehingga masa menganggur jadi lebih lama.

Kemudian pengujian statistik yang dilakukan terhadap variabel status dalam rumah tangga juga tidak signifikan berpengaruh terhadap peluang terjadinya pengangguran di Provinsi Bengkulu. Hal ini sejalan dengan hasil analisis deskriptif yang menunjukkan bahwa dari 1430 responden yang bekerja sebesar 48 persen berstatus sebagai kepala rumah tangga dan sisanya sebesar 52 persen berstatus sebagai bukan kepala rumah tangga, ini memperlihatkan bahwa responden yang berstatus kepala rumah tangga dan bukan kepala rumah tangga memiliki peluang yang sama untuk bekerja di provinsi Bengkulu. Kenyataan ini berlawanan dengan penelitian Chotib (2007) menyimpulkan bahwa angka pengangguran cenderung terjadi pada penduduk berstatus anak (bukan kepala rumah tangga) dan Hasil penelitian Setyadi (2010) juga menyimpulkan bahwa responden yang berstatus bukan sebagai kepala rumah tangga mempunyai probabilitas mencari kerja yang lebih besar dan lebih lama berada dalam masa mencari kerja, namun hal ini tidak terbukti terjadi di Provinsi Bengkulu. Teori yang menyatakan bahwa penduduk yang aktif mencari kerja di perkotaan lebih tinggi dibandingkan di perdesaan, pencari kerja beranggapan pekerjaan lebih tersedia di perkotaan, sehingga mereka mencari kerja di perkotaan. Hal ini juga menyebabkan penduduk perdesaan bermigrasi ke perkotaan untuk mencari kerja, karena mereka menilai peluang mereka mendapatkan pekerjaan di kota lebih tinggi daripada di perdesaan ternyata tidak terjadi di Provinsi Bengkulu. Hasil pengujian statistik yang dilakukan variabel daerah tempat tinggal tidak signifikan berpengaruh terhadap peluang terjadinya pengangguran di Provinsi Bengkulu. Hal ini juga sejalan dengan hasil analisis deskriptif bahwa dari 32 orang responden yang berstatus pengangguran sebanyak 20 responden tinggal di daerah perdesaan dan sisanya sebanyak 12 responden tinggal didaerah perkotaan, ini diperkirakan disebabkan oleh besarnya pengangguran di daerah - daerah perdesaan yang berbatasan dengan perkotaan sehingga menyebabkan pencari kerja tidak melakukan migrasi dan menetap didaerah perkotaan untuk mendapatkan pekerjaan.

\section{KESIMPULAN DAN SARAN}

Terdapat pengaruh signifikan dari variabel pendidikan dan umur terhadap peluang terjadinya pengangguran di Provinsi Bengkulu, sedangkan variabel sertifikat pelatihan/kursus, jenis kelamin, pengalaman bekerja, status perkawinan, status dalam rumah tangga dan daerah tempat tinggal tidak signifikan berpengaruh terhadap peluang terjadinya pengangguran di Provinsi Bengkulu. Rasio-odd atau peluang untuk variabel pendidikan adalah sebesar 1,55 hal ini bermakna bahwa kemungkinan setiap kenaikan satu jenjang pendidikan, maka akan menaikkan peluang seseorang untuk menganggur sebesar 1,55 kali. Rasio-odd atau peluang untuk variabel umur adalah sebesar 0,30 hal ini bermakna bahwa kemungkinan setiap kenaikan satu tahun umur, maka akan menaikkan peluang seseorang untuk menganggur sebesar 0,30 kali. Berdasarkan hasil penelitian dan pembahasan yang telah dilakukan maka dapat ditarik simpulan bahwa terdapat kecenderungan penduduk yang berusia muda dan menamatkan pendidikan sekolah tinggi memiliki peluang yang besar untuk menjadi pengangguran di Provinsi Bengkulu.

Berdasarkan kesimpulan, maka saran untuk untuk Pemerintah Provinsi Bengkulu adalah :

1. Diharapkan mampu meningkatkan dan memperluas lapangan pekerjaan di sektor formal. 
2. Diharapkan mampu meningkatkan program pembangunan padat karya terutama teknologi produksi padat karya yang mengutamakan tenaga kerja muda.

3. Diharapkan mampu mengembangkan sektor pertanian yang lebih dekat dan menyentuh masyarakat yang merupakan sektor utama lapangan usaha di Provinsi Bengkulu.

4. Diharapkan mampu memperbanyak sekolah yang berorientasi ke penciptaan lapangan kerja, seperti Sekolah Menengah Kejuruan(SMK) dan memperkuat daya saing yang ada dengan memperbanyak bidang keterampilan yang diperlukan untuk pembangunan.

\section{DAFTAR PUSTAKA}

Ananta, Aris. 1993. Ciri Demografis Kualitas Penduduk dan Pembangunan Ekonomi. Jakarta: Lembaga Demografi Lembaga Penerbit FE UI.

Arsyad, Lincolin. 2010. Ekonomi Pembangunan. Yogyakarta: UPP STIM YKPN.

Aryati, Fitri. 2014. Analisis Pengangguran Terdidik di Provinsi Bengkulu. Tesis. Bengkulu: Program Pasca Sarjana Magister Perencanaan Pembangunan Universitas Bengkulu.

Astuti, Maidiana. 2013. Faktor-Faktor Yang Mempengaruhi Lama Menganggur Bagi Pekerja Di Industri Perkebunan Kelapa Sawit Ogan Komering Ulu.Jurnal Ilmiah pada STIE MDP, 2(2):130-149.

Badan Pusat Statistik. 2013. Indikator Pasar Tenaga Kerja Indonesia. Jakarta: Badan Pusat Statistik.

Badan Pusat Statistik. 2013. Perkembangan Beberapa Indikator Utama Sosial Ekonomi Indonesia. Jakarta: Badan Pusat Statistik.

Badan Pusat Statistik. 2016. Statistik Gender Tematik: Potret Ketimpangan Gender Dalam Ekonomi. Jakarta: Badan Pusat Statistik.

Badan Pusat Statistik. 2017. Indikator Pasar Tenaga Kerja Provinsi BengkuluTahun 2017. Bengkulu: Badan Pusat Statistik Provinsi Bengkulu.

Badan Pusat Statistik. 2018. Berita Resmi Statistik (BRS). Bengkulu: Badan Pusat Statistik Provinsi Bengkulu.

Badan Pusat Statistik. 2018. Keadaan Angkatan Kerja Provinsi Bengkulu Februari 2018.Bengkulu: Badan Pusat Statistik Provinsi Bengkulu.

Barret, Nancy S dan Morgenstern, Richard S. 1974. Why do Black and Women Have High Unemployment Rate?. The Journal of Human Resources. 9(4): 452-464.

Budhi, Sri Made .2008. Mengelola Sumber Daya Manusia Menyongsong Millenium Development Goals (MDGs). Jurnal Ekonomi dan Sosial. 4(8): 82-85.

Chotib. 2007. Menyiapkan Tenaga Kerja yang Berkualitas Menyambut Jendela Kesempatan Jurnal Warta Demografi. 3(3): 22-38.

George, J. Borjas. 2004. Labor Economics Third Edition. United States of America: McGraw

Gujarati, Damodar. 2007. Dasar-Dasar Ekonometrika. Edisi 3, jilid 2. Jakarta: Erlangga.

Harfina, Dewi. 2007. Faktor-Faktor Yang Mempengaruhi Pengangguran Terselubung Di Perdesaan Jawa Tengah Analisis Data Sakernas 2007. Jurnal Puslit Kependudukan LIPI. 4(1): 15-32.

Hauster, Phillip. 1977. Penduduk dan Masa Depan Perkotaan. Jakarta: Yayasan Obor

Imarotus, H. 2013. Pengaruh Tingkat Pendidikan Terhadap Tingkat Pengangguran di Kabupaten Jombang. Jurnal Fakultas Ekonomi UNESA. 1(3): 1-16. 
J Simanjuntak, Payaman. 2001. Pengantar Ekonomi Sumber Daya Manusia. Jakarta: Penerbit FE UI.

Khotimah. 2009. Diskriminasi Gender Terhadap Perempuan Dalam Sektor Pekerjaan. Jurnal STAIN Purwokerto. 4(1): 1-11.

Kuncoro, Mudarajad. 2006. Ekonomi Pembangunan. Jakarta: Salemba Empat.

Mankiw, N. Gregory. 2012. Pengantar Ekonomi Makro Edisi Asia(terjemahan). Jakarta: Salemba Empat

Mantra, Bagus Ida. 2009. Demografi Umum. Yogyakarta: Pustaka Pelajar Offset.

Nachrowi, Djalal dan Hardius Usman. 2002. Penggunaan Tekhnik Ekonometrik. Jakarta : PT Raja Grafindo Persada.

Nanga, Muana. 2005. Makro Ekonomi: Teori,Masalah, dan Kebijakan. Jakarta:PT Grafindo Persada.

Samuelson, Paul A dan Nordhaus, William D. 2004. Ilmu Makro Ekonomi. Jakarta :PT.Media Edukasi.

Sugiyono. 2012. Metode Penelitian Kuantitatif Kualitatif dan R\&D.Bandung: Alfabeta.

Sukirno, Sadono. 2006. Makro Ekonomi Modern. Jakarta: PT Raja Grafindo Persada.

Todaro, M.P. dan Smith, S.C. 2006. Pembangunan Ekonomi. Jilid I Edisi Kesembilan. Jakarta : Erlangga.

Wing, W. W. 2015. Analisis Ekonometrika dan Statistika dengan Eviews edisi 4. Yogyakarta : Unit Penerbit dan Percetakan. 